\title{
Normative data of median nerve conduction in the state of Haryana
}

\author{
Naresh Kumar ${ }^{1}$, Sakshi $^{2}$, Kirti Sharma, ${ }^{3, *}$, Sibadatta Das ${ }^{4}$, Amit Saxena $^{5}$ \\ ${ }^{1}$ Associate Professor, ${ }^{2}$ MDS Prosthodontics, ${ }^{3}$ Demonstrator, ${ }^{4}$ Associate Professor, ${ }^{5}$ Professor and Head, Dept. of Physiology, \\ ${ }^{1,3,4}$ SHKM Government Medical College Nalhar, Mewat, Haryana, ${ }^{2}$ PDM Dental College and Research Institute, Bahadurgarh, \\ Haryana, ${ }^{5}$ SGT Medical College Budhera, Gurugram, Haryana, India
}

*Corresponding Author:

Email: kirti75kirti@gmail.com

\begin{abstract}
Introduction: For evaluation of peripheral nerve function, nerve conduction study (NCS) is done all over the world. Nerve conduction study can be used in a dual way i.e. prognostic as well as the diagnostic tool. As nerve conduction study is dependent on many factors such as age, height, weight, temperature, gender etc. there is a great variation between standard normal values accepted in different parts of world.

Objectives: Till now we are using standard values adopted by western countries like USA, Canada, Europe etc as normative data for our population because it is not found in literature. Hence this study was designed to find out normative data for population of Haryana, on the basis of which, we can draw a comparison between normative data of our region to the standard values adopted by western countries.

Materials and Methods: This study was taken place in the electrophysiology laboratory of Post Graduate Institute of Medical Sciences, Rohtak. We have studied 330 median nerves. Out of them 116 nerves were of females and 214 nerves were of males. Patients with history of peripheral neuropathy, neuromuscular disease, diabetes mellitus, alcoholism etc were excluded.

Results: Out of the total 330 median nerves studied, 163 were of left side and 167 were on right side. Average age of study group was 34.63 years, height was 158.24 centimeters and weight was 57.02 kilograms. Average latency of the group was $7.39 \pm 1.32$ $\mathrm{ms}$, duration $13.62 \pm 3.69 \mathrm{~ms}$, amplitude $9.48 \pm 5.22 \mathrm{mV}$ with a conduction velocity of $58.61 \pm 5.51 \mathrm{~m} / \mathrm{s}$.

Conclusion: Studies done earlier were lacking statistical power as sample sizes were small including either students or staff members alone. Our study provides normative values of NCS of median nerve to be accepted as reference value in our electrophysiology lab, as population from several places of State of Haryana was studied for median nerve conduction to make a large sample size.
\end{abstract}

Keywords: Nerve conduction study, Normative data, Median nerve.

\section{Introduction}

NCS are done to check the peripheral nerve functions.NCS can be used in a dual way i.e. for diagnosis as well as prognosis of peripheral nerve disorders. ${ }^{1-6}$

NCS is dependent on various factors such as age, gender, temperature, height and weight. ${ }^{7}$

For years various electrophysiology laboratories in our country are using standard values adopted by western countries like America, Canada and Europe to find out various type of neurological problems, though normative data for their population is not precisely applicable to our population. Taking in mind this point of view, the current study has been done to find the normative data of population of Haryana, India.

\section{Material and Methods}

Current study was conducted in the physiology department of PGIMS Rohtak on the patients coming from different parts of State of Haryana. A total of 330 median nerves were studied comprising of left side (163) and right side (167).Out of 330 median nerves, 116 were of females and 214 were of males.

Exclusion Criteria: In our study, mostly healthy individuals were taken. Patients who were taking medication for any disease or having history of neuromuscular disease, cardiac pacemaker, diabetes mellitus, B12 or folate deficiency, thyroid disorder, any neck or back surgery, peripheral neuropathy, alcoholism, entrapment syndrome, chemotherapy were excluded.

\section{Results}

Average age of group was 34.63 years, height 158.24 centimeters and average weight was 57.02 kilograms.

Nerve conduction study included recordings of latency in milliseconds (ms), duration in milliseconds, amplitude in millivolts $(\mathrm{mV})$ and conduction velocity was recorded in meter/second $(\mathrm{m} / \mathrm{s})$. Average latency of the group was $7.39 \pm 1.32 \mathrm{~ms}$, duration $13.62 \pm 3.69 \mathrm{~ms}$, amplitude $9.48 \pm 5.22 \mathrm{mV}$ with a conduction velocity of $58.61 \pm 5.51 \mathrm{~m} / \mathrm{s}$.

Table 1 and Fig. 1 shows demographic profile in males, females and total subjects with level of significant difference.

Table 2 and Fig. 2 shows Nerve conduction parameters in males, females and total subjects. 
Table 1: Demographic profile in males, females and total subjects

\begin{tabular}{|l|c|c|c|}
\hline Group & Age in years & Height in centimeters & $\begin{array}{c}\text { Weight in } \\
\text { kilograms }\end{array}$ \\
\hline Males & $34.71 \pm 16.35$ & $162.56 \pm 15.39$ & $58.51 \pm 15.49$ \\
\hline Females & $34.48 \pm 15.21$ & $150.28 \pm 20.39^{* *}$ & $54.28 \pm 15.21^{*}$ \\
\hline Total & $34.63 \pm 15.94$ & $158.24 \pm 18.25$ & $57.02 \pm 15.50$ \\
\hline
\end{tabular}

$* *=\mathrm{P}<.001, *=\mathrm{P}<0.05$ as compared to males

Table 2: Nerve conduction parameters in males, females and total subjects

\begin{tabular}{|l|c|c|c|c|}
\hline Group & Latency $(\mathbf{m s})$ & Duration $(\mathbf{m s})$ & $\begin{array}{c}\text { Amplitude } \\
(\mathbf{m V})\end{array}$ & $\begin{array}{c}\text { Conduction } \\
\text { Velocity }(\mathbf{m} / \mathbf{s})\end{array}$ \\
\hline Males & $7.29 \pm 1.08$ & $13.62 \pm 3.52$ & $9.58 \pm 5.56$ & $58.46 \pm 5.46$ \\
\hline Females & $7.56 \pm 1.68$ & $13.61 \pm 3.52$ & $9.31 \pm 4.56$ & $58.90 \pm 5.61$ \\
\hline Total & $7.39 \pm 1.32$ & $13.62 \pm 3.69$ & $9.48 \pm 5.22$ & $58.61 \pm 5.51$ \\
\hline $\begin{array}{l}\text { P value of Male } \\
\text { female comparison }\end{array}$ & 0.08 & 0.98 & 0.65 & 0.4 \\
\hline
\end{tabular}

$P$ value $<0.05$ is considered as significant

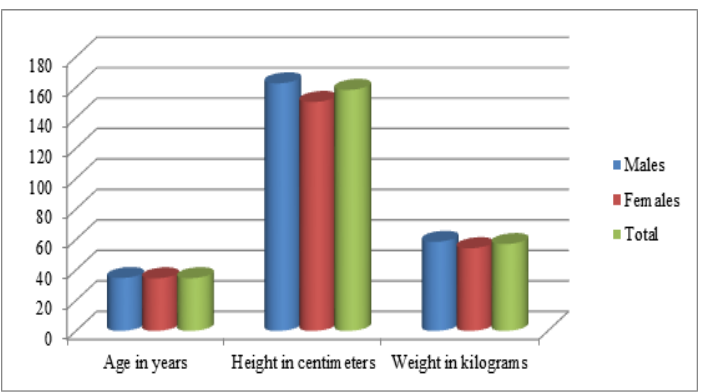

Fig. 1: Diagramatic representation of demographic profile in males, females and total subjects

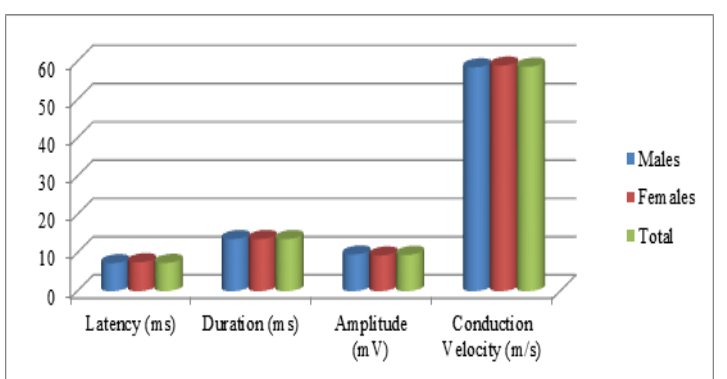

Fig. 2: Diagramatic representation of Nerve conduction parameters in males, females and total subjects

\section{Discussion}

This study was done to find out the normal nerve conduction parameters in population of Haryana so that reference values can be set in our electrophysiology laboratory. Most of studies done in the past were on limited subjects including either students or staff members or office workers. ${ }^{8-11}$ The statistical power of these studies were lacking because of small sample size. A community sampling taking a large sample size was necessary in contrast to above mentioned convenient sampling procedure, hence a large spectrum of population coming from different parts of State of
Haryana was studied for determining the normative data of this region.

The temperature of the arm under our study was kept within 32 to $35{ }^{\circ} \mathrm{C}$ range as this was having a detrimental effect on nerve conduction in contrast to other studies.

In contrast to other studies, the effect of gender was negligible in various nerve conduction parameters like Latency, duration, amplitude and conduction velocity. ${ }^{12-15}$ Though many studies observed the effect of gender on these parameters ${ }^{16,17}$ The finding of difference in latency by Buschbacher ${ }^{18}$ and D. Anton et $\mathrm{al}^{19}$ was more in males. Latency of Median nerve in our study was $7.39 \pm 1.32 \mathrm{~ms}$ which was not in accordance with many studies. ${ }^{21,23,24}$ The reason for this can be instrumentation and procedure of recording i.e. $8 \mathrm{~cm}$ technique or landmark technique.

Amplitude of median nerve in our study was $9.48 \pm$ $5.22 \mathrm{mV}$ which was similar to study done by Robinson et $\mathrm{al}^{20}(9.5 \pm 2.9 \mathrm{mV})$ and Falco et $\mathrm{al}^{21}(9.2 \pm 3.1 \mathrm{mV})$. Studies by Hennessey et $\mathrm{al}^{15}(12.1 \pm 3.8 \mathrm{mV})$, Magladery and Mcdougal $^{22}(12.1 \pm 3.8 \mathrm{mV})$ showed higher amplitude in their study, this difference may be because of short sample size in these studies. While studies by $\operatorname{Kimura}^{23}(7 \pm 3 \mathrm{mV})$ and Owolabi et $\mathrm{al}^{24}$ $(7.7 \pm 2 \mathrm{mV})$ showed lesser amplitude.

Conduction velocity of median nerve in our study was $58.61 \pm 5.51 \mathrm{~m} / \mathrm{s}$. Our findings were similar to that of Hennessey andFalco ${ }^{15}(57 \pm 5 \mathrm{~m} / \mathrm{s})$, Kimura ${ }^{23}(57.7 \pm$ $4.9 \mathrm{~m} / \mathrm{s})$, Mishra and Kalitha ${ }^{25}(58.52 \pm 8.3 \mathrm{~m} / \mathrm{s})$. However study by Owolabi et $\mathrm{al}^{24}(62.5 \pm 4.9 \mathrm{~m} / \mathrm{s})$ showed higher conduction velocity. Duration of nerve conduction was $13.62 \pm 3.69 \mathrm{~ms}$ in our study. Nowhere in literature had we found normative data of duration of median motor nerve study to compare with.

\section{Conclusion}

The acceptance of median nerve recordings in a person from a defined population i.e. normal or not is dependent on what is accepted value range of that 
defined population. The normative value generated for median nerve is dependent on the demographic profile of the subjects being tested. Our study has tried to bring normative data from the population of State of Haryana, India with a mindset that these values will be helpful in making clinical decisions with regards to the patients.

\section{References}

1. Fisher MA. H reflexes and F waves. Fundamentals, normal and abnormal patterns. Neurol Clin 2002;20:339-60.

2. Katirji B. The clinical electromyography examination. An overview. Neurol Clin 2002;20:291-303.

3. North American Spine Society. Electromyogram and Nerve Conduction Study. Available from: http://www.spine.org/ articles/emg_test.cfm. [Last accessed on 2007 Jun 11]

4. Aminoff MJ. Electrophysiology. In: Goetz CG, editor. Textbook of Clinical Neurology. 2nd ed., Ch. 24. Philadelphia: Saunders; 2003. p.4745.

5. Asbury AK. Approach to the patient with peripheral neuropathy. In: Harrison's Principles of Internal Medicine. Part 15: Neurologic Disorders. Nerve and Muscle Disorders. Electrodiagnosis. Ch. 363. Sec. 3. Blakiston, New York (1954).

6. Fuglsang-Frederiksen A, Pugdahl K. Current status on electrodiagnostic standards and guidelines in neuromuscular disorders. Clin Neurophys 2011;122:440455.

7. Kommalage M, Gunawardena S. Influence of age, gender, and sidedness on ulnar nerve conduction. J Clin Neurophysiol. 2013;30:98-101.

8. Dawson GD, Scott JW: The recording of nerve action potentials through skin in man. J Neurol Neurosurg Psychiatry 1949;12:259-267.

9. Jackson DA, Clifford JC: Electrodiagnosis of mild carpal tunnel syndrome. Arch Phys Med Rehabil 1989;70:199204.

10. Melvin JL, Harris DH, Johnson EW: Sensory and motor conduction velocities in the ulnar and median nerves. Arch Phys Med Rehabil 1966;47:511-519.

11. Thomas JE, Lambert EH, Cseuz KA: Electrodiagnostic aspects of carpal tunnel syndrome. Arch Neurol 1967;16:635-641.

12. Hamdan FB. Nerve conduction studies in healthy Iraqis: Normative data. Iraqi J Med Sci. 2009;7:75-92.

13. Garg R, Bansal N, Kaur H, Arora KS. Nerve conduction studies in the upper limb in the malwa regionnormative data. J Clin Diagn Res. 2013;7:201-4.

14. Shehab DK. Normative data of nerve conduction studies in the upper limb in Kuwait: Are they different from Western data? Med Princ Pract. 1998;7:203-8.

15. Hennessey WJ, Falco FJ, Goldberg G, Braddom RL. Gender and arm length: Influence on nerve conduction parameters in the upper limb. Arch Phys Med Rehabil. 1994;75:265-9.

16. Karnain WO, Singh S, Agrawal BK, Kamra M, Gupta S. Gender effect on upper limb nerve conduction study in healthy individuals of North India. J Pharm Biomed Sci. 2013;33:1589-93.

17. Thakur D, Paudel BH, Bajaj BK, Jha CB. Nerve conduction study in healthy individuals, a gender based study. Health Renaiss. 2010;8:169-75.

18. R.M. Buschbacher. Median nerve motor conduction to the abductor pollicis brevis, Am J Phys Med Rehabil 78 (1999), S1- 8 .
19. Dan Anton, Fredric Gerr, Linda Merlino, John C. Rosecrance. Normative median and ulnar nerve conduction values among a rural aged Population. Work 49 (2014) 5-14.

20. Robinson LR, Rubner DE, Wohl PW, Fujimoto WY, Stolov WC: Influences of height and gender on normal nerve conduction studies. Arch Phys Med Rehabil 1993;74: 1134-1138.

21. Falco FJ, Hennessey WJ, Braddom RL, Goldberg G: Standardized nerve conduction studies in the upper limb of the healthy elderly. Am J Phys Med Rehabil 1992;71:263-271.

22. Magladery JW, McDougal DB Jr. Electrophysiological studies of nerve and reflex activity in normal man. I. Identification of certain reflexes in the electromyogram and the conduction velocity of peripheral nerve fibers.Bull Johns Hopkins Hosp 1950;86:265-90.

23. Kimura J. Electrodiagnosis in Diseases of Nerve and Muscle: Principles and Practice. 3rd ed. Philadelphia: Davis; 2001.p. 131-68, 180, 412-3.

24. Owolabi LF, Adebisi SS, Danborno BS, Buraimoh AA. Median nerve conduction in healthy Nigerians: Normative data. Ann Med Health Sci Res 2016;6:85-9.

25. Mishra UK, Kalita J. Clinical Neuophysiology. 2nd ed. New Delhi: B. I. Churchill Livingstone Pvt Ltd.;1999. p.24-9. 